\title{
COUNTERMEASURES BY THIRD PARTY IN INTERNATIONAL LAW
}

\author{
Sefriani \\ Faculty of Law Universitas Islam Indonesia, Indonesia \\ E-mail: sefriani@uii.ac.id
}

\begin{abstract}
The weakness of law enforcement in international law often causes countermeasure, not only done by injured state but also by third party. Countermeasure is not only done by injured state but also by non-injured states. In this research, the two research questions are formulated: countermeasure regulations in international law and countermeasures legality by third party. This research applied normative legal research method conducted through library research. This research used legislation, historical and conceptual approach. Then, the data were analyzed qualitatively and the results of the study were analytical descriptively presented. The result of this research shows that countermeasure by injured state has been accepted under certain conditions. However, Countermeasure done by the third party remains controversial which means that the obscurity requires further regulation to avoid the abusive action.
\end{abstract}

Key words: countermeasure; injured party, third party

\begin{abstract}
Abstrak
Lemahnya penegakan hukum dalam hukum internasional sering menimbulkan tindakan pembalasan (countermeasure). Seringkali Countermeasure tidak hanya dilakukan oleh injured state tetapi juga oleh non injured state. Dua Rumusan Masalah dalam penelitian ini adalah tentang pengaturan tindakan countermeasure dalam hokum internasional dan legalitas countermeasures oleh pihak ketiga. Metode penelitian penelitian hukum normatif, dilakukan melalui library research. Pendekatan penelitian yang digunakan adalah pendekatan perundang-undangan, historis dan penedekatan konsep. Analisis yang dilakukan adalah analisis kualitatif. Hasil penelitian disajikan secara deskriptif analitis. Hasil penelitian menunjukkan bahwa countermeasure oleh injured state telah diterima dengan syarat-syarat tertentu. Adapun Countermeasure yang dilakukan pihak ketiga masih banyak pro dan kontra, ketidakjelasan yang membutuhkan pengaturan lebih lanjut untuk menghindari penyalahgunaan tindakan ini.
\end{abstract}

Kata kunci: countermeasure, injured state, pihak ketiga

\section{Introduction}

At the end of 2016 the international community was struck by the death of the Russian Ambassador to Turkey, who was shot dead by a member of the riot police in Ankara. ${ }^{1}$ Turkish police motive toward the issues is to countermeasure against Russian policy that support the regime of Bashar al-Assad to massacre civil society in Aleppo, Syria. This vengeful act is included into countermeasure by a third party.

Another example is terrorism acts to countries whose policies are considered unfair

Burhan Ozbilici, December 20 th 2016 , Duta Besar Rusia untuk Turki Tewas Ditembak Mati di Ankara, available on website: http://www.bbc.com/indonesia/dunia-3837 3034, accessed on December 24 $4^{\text {th }}, 2016$. to the Muslim community. ${ }^{2}$ For instance, the bombing of American and French troop barracks in Beirut, Lebanon, occurred on October $23^{\text {rd }}$ 1983, when two truckloads of bombs burst through the barracks of the two troops in separate places. The raid killed 299 American and French troops. Next, the Attack on the Twin Towers of the World Trade Center September $11^{\text {th }}$ 2001 bombing and the Qadaffi's assets freeze and Libyan central bank assets by Switzerland in

\footnotetext{
Luis de la Corte and Andrea Giménez-Salinas, "Suicide Terrorism as a Tool of Insurgency Campaigns: Functions, Risk Factors, and Countermeasures", Perspective on Terrorism, Vol. III Issue 1, April 2009, page. 3 available on website: http://www.terrorismanalysts. com/pt/articles/issues/PTv3i1.pdf
} 
February 2011 which was followed by the United States in response to Qadaffi's violence against civilians in Libya. ${ }^{3}$ The same form of countermeasure was also perpetrated by the European Community against the asset from AlAssad presidents and Syrian central bank in May $2011,{ }^{4}$ in response to mass human rights violation and massive humanitarian law carried out by the regime of Bashar al-Assad in Syria. ${ }^{5}$ Furthermore, in November 2011 Arab League decided to suspend Syria membership and freeze the assets of government and senior officials as well as implementing a ban on civil aviation. ${ }^{6}$ Countermeasure occurred in various economic sectors was also conducted by the European Community in March 2014 against Russia which was deemed to commit destabilization in Ukraine. $^{7}$

International law does not clearly regulate the countermeasure committed by third party. Article 48 on Draft articles on the State Responsibility for International Wrongfully Act (ARSIWA) allows other parties, injured States, to hold perpetrators accountable for breachs of liability to the entire international community.

What is formulated in article 48 ARSIWA is reaffirmed in UN General Assembly resolution $56 / 83$ of 2002 on the Responsibility of States for internationally wrongful acts adopted by the UN General Assembly on 28 January 2002. There is no editorial difference between what is stipulated in article 48 ARSIWA and article 48 of UNGA $56 / 83$ of 2002 , which means that what is formulated in ARSIWA is fully accepted by the UN General Assembly. Article 48 (1) ARSIWA complies with Article 42 ARSIWA which regu-

Martin Dawidowicz, "Third-party countermeasures: A progressive development of international law", Question of International Law, Zoom in 29, 2016, page 5.

Available on website: http://www.qil-qdi.org/thirdparty-countermeasures-progressive-development-inter national-law/

Ibid., page 6.

5 Council Implementing Decision 2011/302/CFSP of 23 May 2011 [2011] OJ L 136/91; Council Decision 2012/122/ CFSP of February $27^{\text {th }}, 2012$ [2012] OJ L $54 / 14$. For the most recent renewal of the sanctions regime, see Coun-cil Decision 2015/837/CFSP of 28 May 2015 [2015] OJ L 132/82, as quoted by Martin Dawidowicz, ibid., page. 6

6 Ibid., page 7.

Ibid., page 8 . lates the right of injured state to hold accountable.

Article 49 Draft article on the responsibility of international organizations (DARIO) 2011 also allows a State or international organization to hold accountability to other international organizations that violate the obligations held by the international community as a whole.

However, the articles above leave some questions such as who is meant by injured state as well as a third party? What kind of offense liability that enables parties which are not harmed ask for responsibility? Can countermeasure be done by using armed violence? And there are some more questions. However, this study does not intend to examine and answer all questions. The following research limits itself only to the arrangement of countermeasure, especially in the arrangement of countermeasure by third party in international law. The following article does not intend to address all of the above issues, rather, it will only focus on two issues concerning regulation of countermeasure in international law and the legality of countermeasure acts by third party in international law.

\section{Discussion}

\section{Sanctions, Retorsions and Countermeasures in International Law}

Lack of structured formal institutions such as compulsory legislative, judicial and enforcement procedure often leads to attacks on the existence of international law as a real law. International law is seen nothing more than a system of moral values and principles. ${ }^{8}$

International law is not a real law, it is only as a positive moral force proposed by John Austin decades ago. Austin stated that international law is just a positive morality since it does not have sovereignty as well as sanctions. ${ }^{9}$ Responding the statement, Fitzmaurice argued:

8 Elena Katselli, 2005, "Countermeasures by Non-Injured States in the Law on State Responsibility", Paper, European Society of International Law, available on: http://www.esilsedi.eu/sites/default/files/Katselli_0.P DF

9 John Klabbers, 2013, International Law, Cambridges: Cambridge Univeristy Press, page 165. 
"Law' is not 'law' because it is enforced: it is enforced because it is 'law'; and enforcement would otherwise be illegal..." 10 A view which claimed that international law cannot work due to lack of sanctions is unacceptable since according to anthropologist and sociologist, there are many factors causing public compliance to the law and not only fear to the sanctions. ${ }^{11}$ The problem is actually more on the effectiveness of international law than the issue of qualification as a law or not. ${ }^{12}$

Sanctions are well known in international law. ARSIWA 2001 firmly states that:

"the responsible State is under an obligation to make full reparation for the injury caused by the internationally wrongful act"

This is already a codification of customary international laws relating to reparations that can be traced, in the case of the Chorzow Factory, which was decided by the Permanent Court of International Justice in $1927 .{ }^{13}$

There are some technical terminologies found in international law related to sanctions. Some of them are sanction, reprisal, retorsion, and countermeasure. Generally sanction is often understood as every action done to countries 'to force them to comply with international law or to punish them for violating international law. The term of sanction is often limited to an action done by an international organization relating to the implementation of organization rules. For instance, sanctions from the Security Council concerned to chapter VII of the UN Charter where the sanctions are mentioned in Article 41 of the Charter and the im-

10 Tom Ruys, Sanctions, "Retorsions and Countermeasures: Concepts and International Legal Framework", Forthcoming in Larissa van den Herik (ed.), Research Handbook on UN Sanctions and International Law, Edward Elgar Publishing, page 23, Available on website: https: / / papers.ssrn.com/sol3/papers.cfm?abstract_id=2 760853

11 John Klabbers, Loc.Cit.

12 Tom Ruys, Loc.Cit.

13 Andrew T. 2008, Guzman, How international law works: a rational choice theory, Oxford University Press, Inc., page 55 . plementation will be monitored by the UN Security Council's Sanctions Committee. ${ }^{14}$

African Union adopts 11 situations where organizations are able to implement the sanctions to their members. The practice of countries shows that the terms of sanctions tends to be referred as a sanction under international organization supervision as a punishment of a breach done by a country. ${ }^{15}$ In fact, long before sanction decade was introduced which refers to sanctions from international organizations, the practice of countries has already applied economic sanction which is considered

"less dangerous than military force, but more serious-and sometimes more effective-than diplomacy alone".

As stated earlier besides sanctions, retorsion, reprisal and countermeasures are recognized. Retorsion is a legitimate but unfriendly act undertaken in response to the injurious act of another country, ${ }^{16}$ for instance diplomatic termination, recalling of ambassadors, expulsion of foreigners; Application of travel restrictions; Import export restrictions; suspended development assistance and others. ${ }^{17}$

Different from retorsion, reprisal known as countermeasure ${ }^{18}$ is an illegal action, however it is justified in the name of a response to an international legal action taken beforehand by another party, ${ }^{19}$ Countermeasures are legitimate reprisals, self-protection action or selfhelp. ${ }^{20}$ In contrast, nowadays the use of reprisal

14 Peacebuilding Commission, "Security Council Subsidiary Bodies: An Overiew", available on website: http:// www.un.org/sc/committees, accessed on October $20^{\text {th }}$, 2016.

15 L.J. van den Herik, "Peripheral Hegemony in the Quest to ensure Security Council Accountability for its individualized UN sanctions regimes:' Journal Conflict Security Law, Vol. 19 No. 3, 2014, Oxford: Oxford University Press, page 433.

16 Monica Hakimi, "Unfriendly Unilateralism", Harvard International Law Journal, Vol. 55 No. 1, 2014, Massachussetts: Harvard Law School, page 105.

17 John Klabbers, Op.Cit, page 168.

18 Kuei Jung Ni, "Third State Countermeasure for Enforcing International Common Environmental Interest: The Implication and Inspiration of ILC's Articles on State responsibility", Chinese (Taiwan) Yearbook, Vol. 22, 2004, page 3. Available on website: https://papers.ssrn.com/ sol3/papers.cfm?abstract_id $=1930951$

19 John Klabbers, Loc.Cit.

20 ARSIWA 2001 commentary article 22 paragraph 3, page 75 . 
is limited on the law of belligerent reprisals which involves the use of force. Furthermore, countermeasure is limited on non-forcible meas-ures. ${ }^{21}$

The definition of countermeasure found in ARSIWA commentary: a feature of a decentralized system by which injured state may seek to vindicate its rights and to restore the legal relationship with the responsible State which has been ruptured by the international wrongful act. ${ }^{22}$ A similar definition is given by the UN that defines Countermeasures as:

"a typical element in a decentralized system through which a harmed State can seek to redress its rights, alongside the restoration of the primary legal relationship with the State responsible for the internationally illicit act."23

As for international practice, countermeasure is understood as:

"the reactions of a State to a behavior by another State that considered harmful to its interests. In this fashion, the purpose of such reactions is to restore the state prior to the breach while simultaneously restoring the legal balance that was destabilized by the illicit action." 24

The acknowledgement of Countermeasure by international law can be seen in the formulation of Article 22 ARSIWA 2001. ${ }^{25}$ Although in fact countermeasures itself is an internationally wrongful act but it is excluded from demand for accountability by a reason of restoring an already disturbed balance, aid and protection for self, reciprocal, to urge the country to stop the violence, and to guarantee not to repeat the violence in the future. ${ }^{26}$

\section{Ibid.}

ILC Commentaries on countermeasure, paragraph 1.

23 State Responsibility: Titles and Text of the Draft Articles adopted on the 53th session, Official Records of the UN General Assembly, UN Doc A/56/10 (2001), page 128. available on website: http://legal.un.org/ilc/texts/in struments/english/commentaries/9_6_2001.pdf.

24 John Klabbers, Op.Cit., page 176.

25 Article 22 ARSIWA 2001 decides: The wrongfulness of an act of a State not in conformity with an international obligation towards another State is precluded if and to the extent that the act constitutes a countermeasure taken against the latter State in accordance with chapter II of Part Three.

26 Elena Katseli, Op.Cit., page 2.
Acceptance of countermeasures practice can be seen in Gabcikovo-Nagymaros Project case. Besides, it can also be found in arbitral awards especially in Naulilaa case; Cysne; and Air Service Agreement. ${ }^{27}$ International Court also never condemned United States for doing economic pressure towards Iran as the response of hostage of America's diplomats in Teheran. ${ }^{28}$

Although acknowledging the existence of countermeasure yet ARISWA Commentary strictly restricts the implementation of it. First, Countermeasures are only allowed for non forcible measures. This case is regulated in Article 50 paragraph 1a ARISWA which states that in doing the countermeasures, it is obliged to refrain from using threat or viol-ence as it has been regulated in UN Charter. This provision reflects the fundamental ban in humanitarian law banning reprisal to individual. The reprisal ban can be found in Jenewa Convention 1929, Jenewa Convention 1949 and also additional 1 Protocol year 1977. ${ }^{29}$ Even though there is a serious breach to international law, such as aggression, the reprisal is still unjustified. ${ }^{30}$

Second, Countermeasures must remain respect-ful to fundamental obligation of human rights' protection. ${ }^{31}$ In this case ILC refers to General Comment (1977) the Committee on Economic, Social and Cultural Rights on the effect of economic sanctions on civilian populations and es-pecially on children and also to Article 54 (1) Protocol additional 1 year 1977 which sets that: "starvation of civilians as a method of warfare is prohibited".

Third, countermeasures shall not violate reprisal ban in humanitarian law. ${ }^{32}$ Fourth, countermeasures can only be done by injured state toward the responsible state to force the state to stop its international law breach of

\footnotetext{
27 ARSIWA 2001 commentary Article 22 paragraph 5 page 76

28 Kuei Jung Ni, Op.Cit., page 4.

29 Marco Sassoli, "State Responsibility for Breach of International Humanitarian Law", IRRC, Vol. 84 No. 846, June 2002, International Committee of The Red Cross, page 425, Available on website: https://www.icrc.org/ 30 Ibid. eng/assets/files/other/401_434_sassoli.pdf

31 Article 50 paragraph 1b ARSIWA 2001.

32 Article 50 paragraph 1c ARSIWA 2001a.
} 
obligation and do the reparation. ${ }^{33}$ This matter is confirmed in United Nations, Reports of International Arbitral Awards (UNRIAA), Volume II, 1011 year 1928 in case Naulilaa. Countermeasures are not meant to condemn the responsible state but as a means to achieve the obedience to international law. International court in the Gab cíkovo Nagymaros Project case states that: ${ }^{34}$ In order to be justifiable, a countermeasure must meet certain conditions. In the first place it must be taken in response to a previous international wrongful act of another State and must be dir-ected against that State.

Fifth, countermeasures are only allowed to address to the responsible state, in this case is the state that did the internationally wrongful act. Sixth, countermeasures is temporary. If the responsible state has done its international law obligation, it must be stopped. ${ }^{35}$

Seventh, countermeasures cannot break the peremptory norms in international law. ${ }^{36}$ Eighth, the Implication of countermeasures must remain respectful to dispute resolution which is agreed along with the responsible state. ${ }^{37}$ As for the ninth restriction, Countermeasures must remain respectful to inviolability for diplomatic agent or consular, premises, archives and documents. ${ }^{38}$

Beside all those matters, ARSIWA commentary also added some other guidelines: ${ }^{39}$ that countermeasures is reversible, preceded by request toward country which should be responsible to obey and execute their obligation, and it must be completed with legitimate notification to country offender about countermeasure which need to be taken and negotiation with injured state which in this case is the offender of countermeasure. The important thing is if international wrongful act for prosecutor country did not happen, even there are disad-

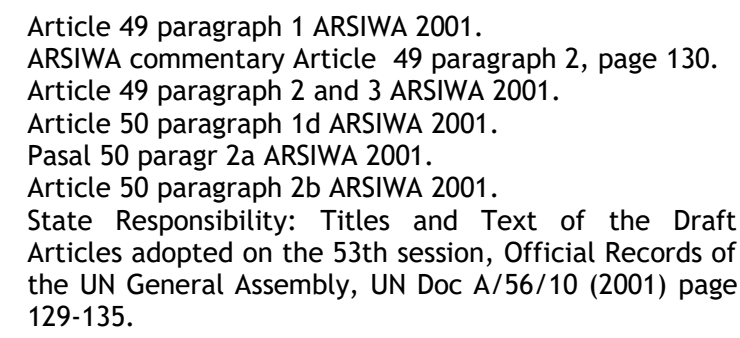

vantages the countermeasure would not be legal. For instance, what Libya did to England in 1971 was unlawful because England failure to prevent Iran occupation over Persia gulf was not international law breach and it was not offense to Libya either. ${ }^{40}$

Still related to limitation of unilateral countermeasures, application of countermeasures must consider necessity and proportionality principle. Necessity means countermeasures as last resort when another way to demand obedience of wrongdoer state failed or ineffective. ${ }^{41}$ Proportionality is used to guarantee equivalence between offender and injured party. Difficulties are often found in terms of measuring equivalent criteria within qualitative standard for breach effect and quantitative standard for gravity of wrongful act. In the case of Gabcikova Nagymaros project, international court found that Checolovaskia action was not proportional since its countermeasure effects have lifted out Hungaria over right for an equitable and reasonable share of the natural resources of the Danube. ${ }^{42}$

Article 51 ARSIWA 2001 stipulates that:

"Countermeasures must be commensurate with the injury suffered, taking into account the gravity of the internationally wrongful act and the rights in question."

In Naulilaa case, arbitration states that:

"even if one were to admit that the law of nations does not require that the reprisal should be approximately in keeping with the offence, one should certainly consider as excessive and therefore unlawful reprisals out of all proportion to the act motivating them."

This article ask injured state to consider two things namely the gravity of the internationally wrongful act, and the rights in question. "the rights in question" has wide meaning, not just about breach effect of injured state but also the right of responsible state, even other countries which could be affected by countermeasure that done by injured state.

\footnotetext{
40 Ibid.

${ }^{41}$ Kuei Jung Ni, Op.Cit., page 18.

42 Ibid.
} 


\section{Countermeasures by Third Party in Interna- tional Law}

Based on previous explanation, it seems that countermeasures done by injured state have been accepted in International law, unlike countermeasures by third party. There are a lot of arguments related to this third party countermeasures legality.

Third-state countermeasures concept appeared along with law doctrine that weight of internationally wrongful acts is not the same. In 1915, Elihu Root distinguished wrongful acts that affect injured state directly from those that affect all country. ${ }^{43}$ This idea developed toward the end of World War II. There was responsibility distribution that is responsibility applied to breach duty that significantly affects international community and responsibility for breach duty that affects directly to injured state. Formulation of article 53 on peremptory norms (jus cogens) also International court decision in Barcelona traction light case confirmed the idea. In this case, the court distinguished obligations in the observance and the protection of which all States have an interest from obligations "arising vis-à-vis another State in the field of diplomatic protection. ${ }^{44}$

Many opinions on qualification of international law breach duty summarized by LinosAlexander Sicilianos are: first, the breach of obligation comes from bilateral relationship in which directly in-jured state confronts default state which com-mits internationally wrongful act, as regulated in article 42 of ARSIWA. ${ }^{45}$

Second, the Breach of obligation comes from multilateral relationship. ${ }^{46}$ ILC calls this obligation as interdependent obligation or erga omnes partes or collective obligation. ${ }^{47}$ The implementation of this obligation by all participant states becomes a sine qua non condition; therefore, the breach of obligation done by a

\footnotetext{
43 Elena Katseli, Op.Cit., page 3.

44 Ibid.

45 Linos-Alexander Sicilianos, "The Classification of Obligations and the Multilateral Diension of the Relations of International responsibility", Europan Journal of International Law, Vol. 13 No. 5, 2002, Oxford: Oxford University, page 1133

46 Ibid.

47 Ibid. , page 1135
}

state in this agreement will influence the interest of other participants and disrupt the objectives and the functions of the proposed agreement. Obligations related to the environment, the security of a region (including disarmament, a regional nuclear-free-zone treaty or a regional system for the protection of human rights) include this category. ${ }^{48}$

Third, the obligation comes from universal relationship. ${ }^{49}$ This obligation is often called as erga omnes obligation, the obligation is possessed by the whole international society. The difference between this obligation and erga omnes partes obligation is that erga omnes partes obligation only belongs to certain states, for instance regional agreement regarding Human Rights protection. On the other hand, erga om-nes obligation universally belongs to all states. This is where the states that are not directly or not individually affected by the act done by de-faulting state appear. These states are not dir-ectly harmed; however, they are affected by the act done by defaulting state..$^{50}$

International Court in Barcelona Traction case acknowledged the existence of certain global obligations of erga omnes where all states have legal interest. ILC also had codified them in ARSIWA 2001, which broadens the concept of alleged injured state by permitting non directly injured parties to do countermeasure. ${ }^{51}$ This matter is regulated in article 48 section (1) of ARSIWA 2001 regarding invocation of responsibility by a state other than an injured State which determines as follows:

"Any State other than an injured State is entitled to invoke the responsibility of another State in accordance with paragraph 2 if: (a) the obligation breached is owed to a group of States including that State, and is established for the protection of a collective interest of the group; or, (b) the obligation breached is owed to the international community as a whole."

\footnotetext{
48 ARSIWA Commentary 2001, as the comment toward article 48 of UN Doc. A/56/10, paragraph 7, page 320 .

49 Linos-Alexander Sicilianos, Op.Cit., page 1136.

50 ARSIWA Commentary 2001, Introduction to the Commentary Pasal 40 dan 41, pararagraf 7. page 281.

51 Kuei Jung $\mathrm{Ni}$, Op.Cit., page 4-5.
} 
Although on article 48 sections (1) is believed as something progressive, it blows various questions such as how come a state that is not injured has the right to file indictment of responsibility to another state? What is the legal ground which gives legitimation to their remedial action? This matter is contradictory with the most basic principle in law that when there is no legal interest infringed there is no right of action ('pas d'intéret, pas d'action') ${ }^{52}$. The answer of this question is that legal ground of remedial action opposes responsible state just because they are the part of international society, that is permitted to act based on action popularis. ${ }^{53}$ The formulation of other than injured state is better replaced by the term like objective and subjective injured state or using the term directly injured and indirectly injured state.

The suggestion is introduced since the term other than injured state is too broad and multi-interpretation. Who is considered as other than injured state? How come those who are not injured state file the prosecution? The terms objective and subjective injured state or indirectly injured state and directly injured state are more acceptable since there is word 'injured'. Based on the law, injured parties have authority to file the prosecution. International law has accepted the concept of indirectly injured state. International crime is the crime toward all humans. The victims are all humans too either directly injured state or injured state.

Some supporting reasons of the third state countermeasures' are as follows: first, the reality of erga omnes obigation. In Barcelona case, the international court explicitly distinguished the state obligation toward international society totally from another obligations. For examples; diplomatic protection norm, prohibition of aggresion acts, genocide, and certain principles which govern human basic rights in-

52 Pierre-Marie Du, "Back to the Future of a Multilateral Dimension of the law of State responsibility for the Breaches of Obligations Owed to the International Community as a Whole", Europan Journal of International Law, Vol. 23 No. 4, 2012, Oxford: Oxford University, page 1061.

53 lbid. cluding the protection of slavery and racial discrimination. The acknowledgement of erga omnes doctrine continued to the next decisions of the International Court such as; in the East Timor case about self determination right as well as in Bosnia case in which the court emphasized the obligation to prevent and to punish the perpetrator of genocide as erga omnes.

Furthermore, in Gabcikovo - Nagymaros Project case, the International Court judge, Weeramantry, stated through his separated opinion that some concepts of environmental law such as sustainable development concept are erga omnes. The acknowledgement of erga omnes created a legal consequence which makes every state has the legal standing and interests. It made every state possibly make de-mands, in line with actio popularis doctrine. This doctrine, which came from Roman, enables every member to take a part to protect the common interest of the community though he did not injured directly. ${ }^{54}$

Second, the Regime of bilateral and collective law enforcement is inadequate. Related to this case, Charley specifically described three situations justifying the countermeasures conducted by the third party.

The first situation is when there is no directly injured state which traditionally has legal standing for remedy such as when genocide attacks certain minority group which belongs to the same state with the prepetrator. The second situation is when there is injured state but it does not afford to do aggresion to the injured state territory. The third situation is when there is injured states which has interests and theoritically can file a remedy but they cannot due to more powerful offender states. Consequently, effective remedy cannot be reached. ${ }^{55}$ In addition, the mechanism of collective law enforcement usually is not effective.

Even though the UN Security Council have the authority to impose sanctions, it is limited to some situations which considered peace threat, breach and aggresion crime. The incap-

Kuei Jung Ni, Op.Cit., page 7.

Ibid. 
ability of UN to enforce internationa law strengthen the solving argument through unilateral countermeasures ${ }^{56}$

Despite many supports, the countermeasures of the third party receive some refusals. The first refusal is potential right abuse. Since the obligation of erga omnes has not been well defined yet, there is a worry that the third party would wrongly interpret its interests on behalf of protecting erga omnes values. Furthermore, currently there is no adequate control from the judicial or international politics institution to this third state countermeasures both by international convension and the international behavior law.

This condition raises the stake to create a serious breach dominated by some powerful states which take a part like a world police or prosecutor. They feel free to use the discretion to select the target state. They can freely decide which action that will be taken as Weil postulated in his observation:

"That would mean that any state, in the name of higher values as determined by itself, could appoint itself the avenger of the international community. This under the banner of law, chaos and violence would come to reign among States, and international law would turn on and rend itself with the loftiest of intentions." 57

The second argument is that the third state countermeasures will potentially trigger conflicts between the existing enforcement mechanisms and will limit directly injured states choices to earn remedy. ${ }^{58}$

The concern on the misuse of Article 48 by the third party to do countermeasures excessively to defaulting state is based on sensible reason since ARSIWA left a lot of questions for its legality and limitation to the implementation of Article 48. Chapter II about countermeasures consists of Article 49-54. Article 49-53 are appointed to explain further about Article 42 on

\footnotetext{
56 Ibid.

57 Prosper Weil, "Towards Relative Normativity in International Law", American Journal of International Law, Vol. 77 No. 3 July 1983, American Society of International Law, page. 433, Available on website: http://www.jstor.org/stable/2201073

58 Kuei Jung Ni, Op.Cit., page. 11
}

Invocation of responsibility by an injured state, it is not meant to explain further on Article 48 on Invocation of responsibility by a State other than an injured State. According to Pierre Marie Dupuy, those articles are not suitable to explain Article $48 .{ }^{59}$

Article 54 of ARSIWA entitled Measures taken by States other than an injured State mentions:

"This chapter does not prejudice the right of any State, entitled under article 48, paragraph 1, to invoke the responsibility of another State, to take lawful measures against that State to ensure cessation of the breach and reparation in the interest of the injured State or of the beneficiaries of the obligation breached."

Commentary from Article 54 does not provide the appropriate and expected explanation either; thus, experts of law stated that ILC implements saving clause policy as countermeasures regulation by the third party. Further explanation related to the implementation of countermeasures by third party or state other than injured state is highly required in order to prevent abuse of this Article and trigger new breach of international law.

Regarding the pros and cons for third state countermeasure as mentioned above, the solution provided is that the mechanism of law enforcement to erga omnes is done collectively, comprehensively, centrally and efficiently under the command and oversight competent international authority. Unfortunately, this kind of mechanism can only be found if there is world government under international legal system, which until now has not yet been realized. The proposal that third states remedies needs to be in collective regime is not adopted in ARSIWA. This proposal tries to prevent; therefore, every country has freedom to do unilateral countermeasure without realizing the consequences that in fact they are unlawful. ${ }^{60}$

Despite the numerous shortcomings in ARSIWA, contemporary international law has

\footnotetext{
59 Pierre-Marie Dupuy, Op.Cit., page 1062.

60 Ibid, page 14.
} 
been enriched with new principles, new provisions, and new concepts of breach of obligations with legal consequences. Today, International law recognizes not only the principle of reciprocity between two countries but also a new mechanism that allows parties to not directly impair those who hold accountable. This is necessary along with the lack of compulsory jurisdiction in international law. With the recognition of this new mechanism, international law no longer protects only sovereign states but also individuals and people. ${ }^{61}$

\section{Conclusion}

Based on the result of the conducted analysis, there are two conclusions: First, Countermeasures by injured state has been widely accepted both in international treaties, customary international law and court decisions. Second, countermeasure done by the third party is new development from international law approved in Article 48 of ARSIWA Year 2001 when there was erga omnes breach. Its legality is based on the doctrine of actio popularis. However, this article still requires further regulation regarding the limitation of its application in order to avoid misuse for the interest of the third party concerned.

\section{Suggestion}

Further regulation of countermeasures by third parties is necessarily required in relation to application of restrictions to prevent it from abuse.

\section{References}

Dawidowicz, Martin. "Third-party countermeasures: A progressive development of international law". Question of Onternational Law. Zoom in 29. 2016. Available on website: http://www.qil-qdi.org/thirdparty-countermeasures-progressivedevelopment-international-law/;

de la Corte, Luis and Andrea Giménez-Salinas. "Suicide Terrorism as a Tool of Insurgency Campaigns: Functions. Risk Factors. and Countermeasures". Perspective on Ter-

\footnotetext{
61 Kuei Jung Ni, Op.Cit., page 9.
}

rorism. Vol. III Issue 1. April 2009. Available on website: http://www.terrorism analysts.com/pt/articles/issues/PTv3i1.p df;

Hakimi, Monica. "Unfriendly Unilateralism". Harvard International Law Journal. Vol. 55 Issue. 1. 2014. Massachussetts: Harvard Law School;

Jung Ni, Kuei. "Third State Countermeasure for Enforcing International Common Environmental Interest: The Implication and Inspiration of ILC's Articles on State responsibility". Chinese (Taiwan) Yearbook. Vol. 22 (1-47). 2004. Available on: https://papers.ssrn.com/sol3/papers.cfm ?abstract_id=1930951;

Katselli, Elena. 2005. "Countermeasures by Non-Injured States in the Law on State Responsibility". Paper. European Society of International Law. Available on: http://www.esilsedi.eu/sites/default/fil es/Katselli_0.PDF;

Klabbers, John. International Law. Cambridge Univeristy Press. 2013;

Linos-Alexander Sicilianos. "The Classification of Obligations and the Multilateral Diension of the Relations of International responsibility". Europan Journal of International Law. Vol. 13 Issue. 5. 2002. Oxford: Oxford University;

Ozbilici, Burhan. 20 December 2016. Duta Besar Rusia untuk Turki Tewas Ditembak Mati di Ankara. Available on: http://www.bbc. com/indonesia/dunia-38373034. accessed on December 24 $4^{\text {th }}$, 2016;

Peacebuilding Commission. "Security Council Subsidiary Bodies: An Overiew". Available on: http://www.un.org/sc/committees. accessed on October $20^{\text {th }}, 2016$;

Pierre-Marie Du. "Back to the Future of a Multilateral Dimension of the law of State responsibility for the Breaches of Obligations Owed to the International Community as a Whole". Europan Journal of International Law. Vol. 23 No. 4. 2012. Oxford: Oxford University;

Ruys, Tom. Sanctions. "Retorsions and Countermeasures: Concepts and International Legal Framework". Forthcoming in Larissa van den Herik (ed.). Research Handbook on UN Sanctions and International Law. Edward Elgar Publishing. Available on website: https://papers.ssrn.com/sol3/ papers.cfm?abstract_id=2760853; 
Sassoli, Marco. "State Responsibility for Violation of International Humanitarian Law". IRRC. Vol. 84 No. 846. June 2002. International Committee of The Red Cross. Available on website: https://www.icrc. org/eng/assets/files/other/401_434_sass oli.pdf;

T, Andrew. 2008. Guzman. How international law works: a rational choice theory. Oxford University Press. Inc.;

van den Herik, L.J.. "Peripheral Hegemony in the Quest to ensure Security Council Accountability for its individualized UN sanctions regimes:'. Journal Conflict Security Law. Vol. 19 Issue. 3. 2014. Oxford: Oxford Univesity Press;

Weil, Prosper. "Towards Relative Normativity in International Law". American Journal of International Law. Vol. 77 Issue. 3 July 1983. American Society of International Law. Available on website: http://www. jstor.org/stable/2201073. 